\title{
The Impact of Motivation in Increasing Employee Productivity in College
}

\author{
Hadi Purnomo \\ Master of Management Study Program, Postgraduate Faculty \\ Universitas Komputer Indonesia \\ Bandung,Indonesia \\ Hadi.purnomo@email.unikom.ac.id
}

\author{
Rahma Wahdiniwaty \\ Master of Management Study Program, Postgraduate Faculty \\ Universitas Komputer Indonesia \\ Bandung,Indonesia \\ rahma@unikom.ac.id
}

\begin{abstract}
The purpose of this research is to know the big impact of work motivation by employees against the productivity in college. The method that we use in this research is descriptive verification. The analysis unit is the employees of the College, namely Indonesia Computer University (UNIKOM) using the census method by the number of respondents as many as 152 employees. Data analysis uses a validity and reliability test, Lisrel 8.7. The result showed that there was a positive impact of motivation in the workplace against employee productivity at the College.
\end{abstract}

Keywords-discipline, work productivity

\section{INTRODUCTION}

The world of education is currently developing very rapidly, competition between educational institutions is not only from domestic institutions but also from foreign institution, this is one of considerations in determining the strategies to be taken by organization to adjust current conditions. Indonesian Computer University is one of the institutions engaged in the field of education services have the impact of competition in generally in Indonesia and West Java in particularly.Unikom is one of the private universities in West Java, which was established in 2000, has 152 employees. Unikom is a university that put forward the information technology in teaching and learning process. A very good quality of human resources is required during this competition at present.

In order to improve the quality of universities in Indonesia, it is necessary to improve the quality of human resources in this case the education staff and education personnel in supporting quality improvement in the world of education today. The power of educators and education personnel is a very influential factor in the high competition among universities. In order to improve the quality of institutions in Indonesia, the quality of human resources or the employees must be increased in supporting the improvement of the quality of service to students. For this reason, it requires good employee productivity to achieve company goals; Productivity is defined as the output of labor per day[1]. Many factors that affect productivity, one of them is work motivation. In prior research, low productivity was identical with a low motivation problem that rose when individuals felt no value and contingency between their contribution and the results will not be achieved, also because of the cost of contribution itself was excessive[2].

The low motivation of employees in Unikom are indicated based on the results of the questionnaire stating that $56 \%$ of respondents answered "no" to the questions given about productivity level impact and $40 \%$ answered "no" to the question given about to increase the productivity.Prior research concluded that motivation is an inducement for higher output must be given a place by the leader for industrial construction to achieve higher productivity, which will lead to a greater contribution to national gross domestic output [3].

Motivation to improve HR practices such as financial incentives significantly affect employee productivity and performance [4]. Many organizational leaders and behavioral scholars consider the dynamic relationship between motivation and sustainable business as the key to understanding and predicting the productivity of human resources [5]. The importance of choosing the right form of motivational tool in the hotel business to increase productivity[6]. Change or influence motivation levels is secured or stabilized the job, which can raise the output of worker productivity in organizations [7]. This illustrates the magnitude of the influence of motivation on employee productivity in an organization. Our thoughts, beliefs, ambitions, and goals are the aspect of motivation. The main aspect of employee motivation is building organizational structure [8].

Ones who most interested in motivational studies are the leaders who can be a role model and give the understanding how the people can work like they do, so this type of leader can increase and change worker productivity [9]. Regarding to prove this, the researcher intends to conduct a research with the title Impact of Work Discipline in Increasing Employee Productivity in College.

\section{METHOD}

The method we use in this research is descriptive verification. Descriptive method is a method of examining the status, group of people, objects, and systems of thought or class of events in the present[10]. The unit of analysis is the employees of Higher Education, namely the Indonesian Computer University (UNIKOM) using census methods with the total number of respondents with all administrative employees totaling 152. 152 employees using questionnaires for all administrative employees. Data analysis uses validity and reliability tests, Lisrel 8.7. 


\section{RESULT AND DISCUSSION}

The results show that there is a positive impact. motivation in workplace against employee productivity at the College.

TABLE I. RECAPITULATION OF RESPONDENTS RESPONSES ABOUT

MOTIVATION

\begin{tabular}{|c|c|c|c|}
\hline Indicator & Skor & Mean & ategory \\
\hline Salary / Wage & 810 & 2,66 & Good enough \\
\hline Bonus & 1045 & 3,44 & enough \\
\hline Award & 1185 & 3,90 & enough \\
\hline Working Conditions & 1175 & 3,87 & enough \\
\hline Responsibility & 1136 & 3,74 & enough \\
\hline Total and average & $\mathbf{5 3 5 1}$ & $\mathbf{3 , 5 2}$ & Height \\
\hline
\end{tabular}

Overall the results of processing presented in table 1 produces a score of 810 and an average value of 2.66 for the salary / wage indicator, for the bonus indicator produces a score of 1045 with an average value of 3.44, the award indicator gets a score of 1185 with a value an average of 3.90, then the work condition indicator gets a score of 3.87 with an average value of 3.87 and for the responsibility indicator of 1136 with an average of 3.74 . The total indicator is 5351 with an average of 3,52 .

Furthermore, a partial test is conducted to further test which variables among the three variables have a significant effect on work productivity at the Indonesian Computer University. In the partial test each independent variable used $\mathrm{t}$ test which will be compared with the value of $\mathrm{t}$ table at the $5 \%$ error rate and 148 degrees of freedom in the two-way test that is equal to 1.976 .

The results of the research hypothesized that work motivation affects the work performance of employees at the Indonesian Computer University; therefore researchers should set the hypothesis for testing of two parties with the formulation of the statistical hypothesis as follows:

$\mathrm{H}_{0}: \rho \mathrm{YX}_{2}=0$ Work motivation does not affect employee work productivity at the Indonesian Computer University.

$\mathrm{H}_{1}: \rho \mathrm{YX}_{2} \neq 0 \quad$ Work motivation affects the work productivity of employees at the Indonesian Computer University.

TABLE II. TEST RESULTS OF THE EFFECT OF WORK MOTIVATION ON WORK PRODUCTIVITY

\begin{tabular}{|l|c|c|c|}
\hline $\begin{array}{l}\text { Path } \\
\text { Coefficient }\end{array}$ & $\mathbf{t}_{\text {count }}$ & $\mathbf{t}_{\text {table }}$ & Ho \\
\hline 0,377 & 5,695 & 1,976 & rejected \\
\hline
\end{tabular}

In table 2 can be seen the value of tcount the influence of work motivation (5.695) is greater than table (1.976). Because tcount is greater than ttable, then at the error rate $5 \%$ it is decided to reject Ho so $\mathrm{Ha}$ is accepted. This means that work motivation affects the work productivity of employees at the Indonesian Computer University. The results of this test provide empirical evidence that high work motivation will increase employee performance. Work motivation has an effect of $14.2 \%$ on work productivity.

Directly work motivation has an effect of $14.2 \%$ on work productivity, and indirectly because of its relationship with organizational culture and work discipline has an influence of 11.2 percent. So in total the influence (contribution) of work motivation in increasing employee productivity at the Indonesian Computer University by 25.4 percent.

\section{CONCLUSION}

In general, the level of motivation of Indonesian Computer University employees has been good, this can be seen from its influence on the level of productivity of Indonesian Computer University employees, motivation is an important factor in increasing employee productivity, therefore the company is required to create a system of motivation that is focused on employees.

In this study, gameplay begins with "verbing" and ends with feedback; verbing - action - effect - appreciation as a feedback. The verbing initiates the players' actions. Based on the data, clauses are constructed by verbal groups with base forms taken for verbing and nominal groups. Data make the subjects implicit in grammatical structure. The subjects are referred to the players themselves.

Data are classified based on: (1) type of activities; (2) the elements constructing the clauses; (3) role in exchange; (4) types of moods. The data classification is shown in TABLE I.

\section{ACKNOWLEDGMENT}

We would like to acknowledge Universitas Komputer Indonesia to support the fund of the research.

\section{REFERENCES}

[1] Akindele , O A ,'Craftsmen and Labour Productivity in the Swaziland," 2003.

[2] Shepperd, James A. "Productivity loss in performance groups: A motivation analysis." Psychological bulletin 113.1 67.1993.

[3] Aiyetan, Ayodeji Olatunji, and A. O. Olotuah. "Impact of motivation on workers' productivity in the Nigerian construction industry." Proceedings 22nd Annual ARCOM Conference, 2006.

[4] Faisal Ahammad, Mohammad, et al. "Behavioral ambidexterity: The impact of incentive schemes on productivity, motivation, and performance of employees in commercial banks." Human Resource Management 54.S1: s45-s62,2015.

[5] Estes, Brent, and Barbara Polnick. "Examining motivation theory in higher education: An expectancy theory analysis of tenured faculty productivity." International Journal of Management, Business, and Administration 15.1: 1-7,2012.

[6] Cetin, Ibrahim. "Motivation and its impact on labour productivity athotel business "a conceptual study"." International Journal of New Trends in Arts, Sports \& Science Education (IJTASE) $2.1:$ 70-79, 2012.

[7] Estes, B. C, "Predicting productivity in a complex labor market: A sabermetric assessment of free agency on Major League Baseball player performance," Business Studies Journal, 3, (Special Issue 1), 23-58, 2011.

[8] Çiftçi, B, Çalışma İlişkileri ve Güven, Finans Politik ve \&Ekonomik Yorumlar Cilt 46, Sayı 530, 2009.

[9] Valencia, Carla. "Motivation and Productivity in the Workplace," The Myriad,2014. 
[10] Sugiyono, "Metode Penelitian dan pengembangan,penerbit Alfabeta Bandung (Method of Research and Development, Publisher - Alfabeta
Bandung)," 2015. 